Dehydration muscle

electrolyte neutron activation

homeostasis skin

infants water equilibrium

\title{
Variations of Water and Electrolyte Composition of Muscle and Skin in Infants Suffering Acute Dehydration
}

\author{
Jaciues Dubois ${ }^{[40]}$ \\ Department of Pediatrics, Université Libre de Bruxelles, Brussels, Belgium
}

Extract

Variations in the composition of muscle tissue have been studied by neutron activation analysis of microbiopsies in 66 children dehydrated as a result of diarrhea.

In the great majority of cases (53 children) no significant potassium depletion was found in muscle.

In 23 cases of hypertonic dehydration, muscle tissue showed an important loss of water in 20 cases and a significant increase of sodium content in 20 cases and of chloride content in 15 cases. Hypertonicity of tissular water was observed.

In hypotonic dehydration (21 cases), muscle tissue remained normally hydrated and in one-third of all cases, a low sodium and chloride content was found. Hypotonicity of tissular water was observed.

Analysis of skin tissue, performed in 21 of these children, showed essential differences; in the majority of cases, including those with hypotonic dehydration, there was an important reduction of the water content of skin without any detectable changes in the amount of electrolytes.

The differences in behavior of muscle and skin tissues in acute dehydration were confirmed by the study of seven children with hypotonic dehydration at the time of admission and after complete recovery. In those cases, the increase of cutaneous hydration during treatment was not accompanied by any significant variations in the amount of muscle water.

The absence of any significant correlation between variations of plasma chloride concentration and the concentration of chloride in skin water confirms the experimental data showing that, in contrast to other tissues, i.e., muscle, the movement of water between plasma and skin is not accompanied by parallel movement of chloride ions.

\section{Speculation}

The data presented in this study suggest that skin may be considered as a mobile depot for water which acts as an emergency regulator for the maintenance of water content of tissues that are richer in cells, such as muscle. Hypotonic dehydration represents a good illustration of this statement.

Since only 14 of the 66 dehydrated children studied presented a significantly decreased value of muscle potassium, it seems likely that there exists no systematic cellular depletion of potassium in acute dehydration consecutive to diarrhea of short duration. 


\section{Introduction}

Dehydration in infancy is a complex clinical syndrome which is the result of the interaction of different factors. Among these, hydric depletion, electrolytic losses, and metabolic acidosis result in considerable disturbances of the hydroelectrolytic equilibrium of the body. The importance of the hydric and electrolytic disturbances not only depends on the clinical circumstances (diarrhea, vomiting, and fever) but also on the nature of the compensatory intake which may have been given at the beginning of the disease. The relative importance of the hydric and electrolytic losses is partially reflected by the variations of plasma electrolyte concentration. Variations of body composition in dehydration have been studied in children by indirect methods only, i.e., water, electrolyte, and nitrogen balances. The results of those investigations led to the establishment of the theoretical data on which the treatment of dehydration is based $[4,6,7,24]$. The therapeutic implications of those investigations are no longer a matter of discussion. Nevertheless, it is important to note that these methods do not permit the study of the variations of the composition in different tissues. A direct approach of this last problem has been devised in experimental studies in which the disturbances of tissular hydroelectrolytic composition induced by variations of extracellular osmolarity are explored. It has thus been possible to show that a decrease of the plasma sodium concentration is accompanied by an increase of intracellular water resulting in cellular hypotonia. However, the decrease of the concentration of ions in the intracellular space is not proportional to the severity of the hyponatremia [5, 36]. Furthermore, experimental studies have shown that, as a result of variations of extracellular osmolarity or body hydration, or both, water and electrolyte content are regulated independently by each tissue $[5,21,25,28,34,35$, 36].

This work investigates the variations in the composition of two tissues of different structure, muscle and skin, in relation to the disturbances of plasma osmolarity consecutive to acute diarrhea.

\section{Materials and Methods}

\section{Subjects Studied}

The analysis of the muscle of 66 acutely dehydrated infants 2 weeks-18 months old was carried out. The cutaneous tissue of 21 of these children was analyzed as well.
Specimens of muscle and skin were taken immediately upon admission of the children to the hospital and before any therapy was started. Informed consent was obtained in each case [37] and no complications were encountered.

In 14 children, muscle and skin hydration were measured at the time of admission to the hospital and after complete recovery.

In all the infants included in the study, the dehydration was consecutive to an acute enteritis of 48-hr maximum duration. Vomiting was infrequent and did not contribute significantly to the dehydration. Previous to the acute illness, all the children had been in good health and were within normal percentiles for weight and height. Children with associated pathologic conditions such as vitamin deficiency, caloric malnutrition, and gastric or duodenal pathology were excluded from the study.

All the infants presented the clinical characteristics of acute dehydration, i.e., loss of skin turgor, enophthalmia, and sunken fontanel. The weight loss calculated in proportion to the weight of the child prior to the disease was always $10 \%$ or more.

For each individual case, age, weight, anamnestic data, weight loss and plasma values are presented in Appendices 1-4.

We arbitrarily considered as hypertonic dehydration the cases with a natremia over $150 \mathrm{mEq} /$ liter and as hypotonic dehydration the cases with a natremia under $130 \mathrm{mEq} /$ liter. With these criteria in view, we divided the children into three groups: hypertonic dehydration (23 cases), hypotonic dehydration (21 cases), and isotonic dehydration (22 cases).

\section{Methods}

Muscle biopsy (1-2 mg dry weight) was taken by a needle from the external muscle mass of the thigh. Tissue water was measured after desiccation at $100^{\circ}$, and sodium, chloride, potassium, and phosphorus were analyzed by neutron activation. Sampling and determination procedures have been described in detail elsewhere $[12,13,14]$.

A skin fragment (1-3 mg dry weight) was excised at the biopsy site. Unlike the muscle sampling, it was difficult to avoid a certain degree of blood contamination during the skin biopsy. Therefore, the sample of skin tissue was carefully blotted with filter paper to remove surface blood. As skin tissue is much less hydrated than muscle tissue, the error in the determination of water resulting from this manipulation is less important. 

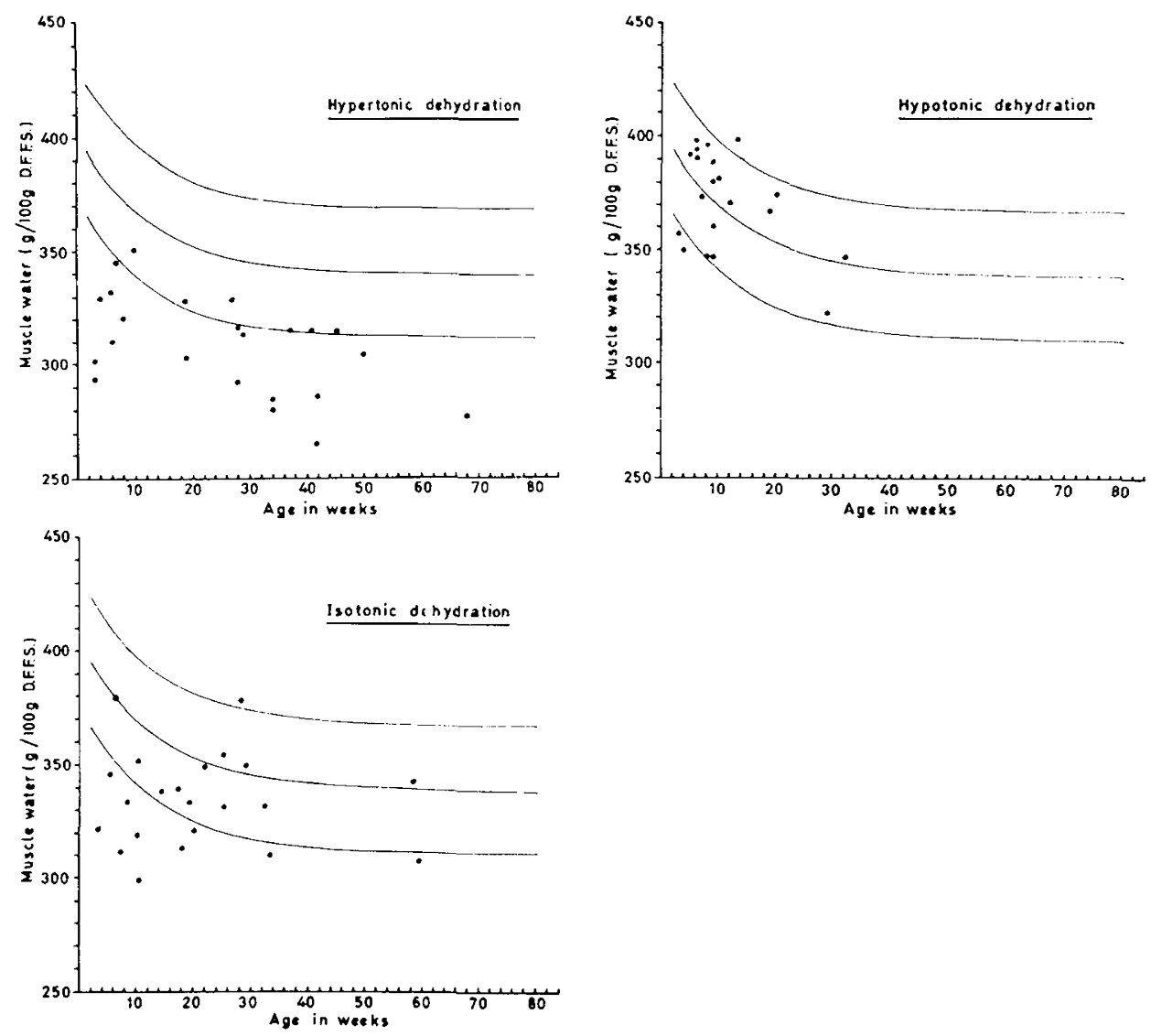

Fig. 1. Water content of muscle in the three groups of dehydrated children. The results are presented in comparison to the mean \pm 2 sD calculated in rclation to age for individual values of a reference group. D.F.F.S.: dry fat-free solid.

Skin water and ions (sodium, chloride, potassium, and phosphorus) were determined by the same methods as those used for muscle tissue.

\section{Results}

The individual results of muscle and skin values are presented in Appendices 1-3.

Figures 1-5, respectively, show the values of water, sodium, chloride, potassium, and phosphorus in muscle in the three groups of dehydrated children.

The results of the analysis are presented in relation to the weight of dry fat-free solid and in comparison to the mean $\pm 2 \mathrm{sD}$ calculated in relation to age for individual values of a reference group of 69 children $[10,11]$.

Figures 6 and 7 show the individual values of water and ions in skin in relation to age in dehydrated children. A representation similar to that used for muscle analysis has been adopted. Because only a limited number of skin analyses could be performed, the separation of the results into three different groups of subjects has not been made.

Figure 8 shows the variations of muscle and skin hydration before and after treatment of dehydration in two groups of children: one with hypertonic dehydration (seven cases) and one with hypotonic dehydration (seven cases). The individual values for water content of the muscle and skin of these children are presented in Appendix 4.

Figure 9 shows the relation between plasma chloride concentration and the concentration of chloride in skin water in 19 of the 21 children studied, and figure 10 shows the relation between the concentrations of chloride in water of plasma and muscle in the 66 dehydrated children.

\section{Discussion}

The group of infants studied was homogeneous as concerns the cause of dehydration, the length of the process, and the fact that acute diarrhea was the only path- 

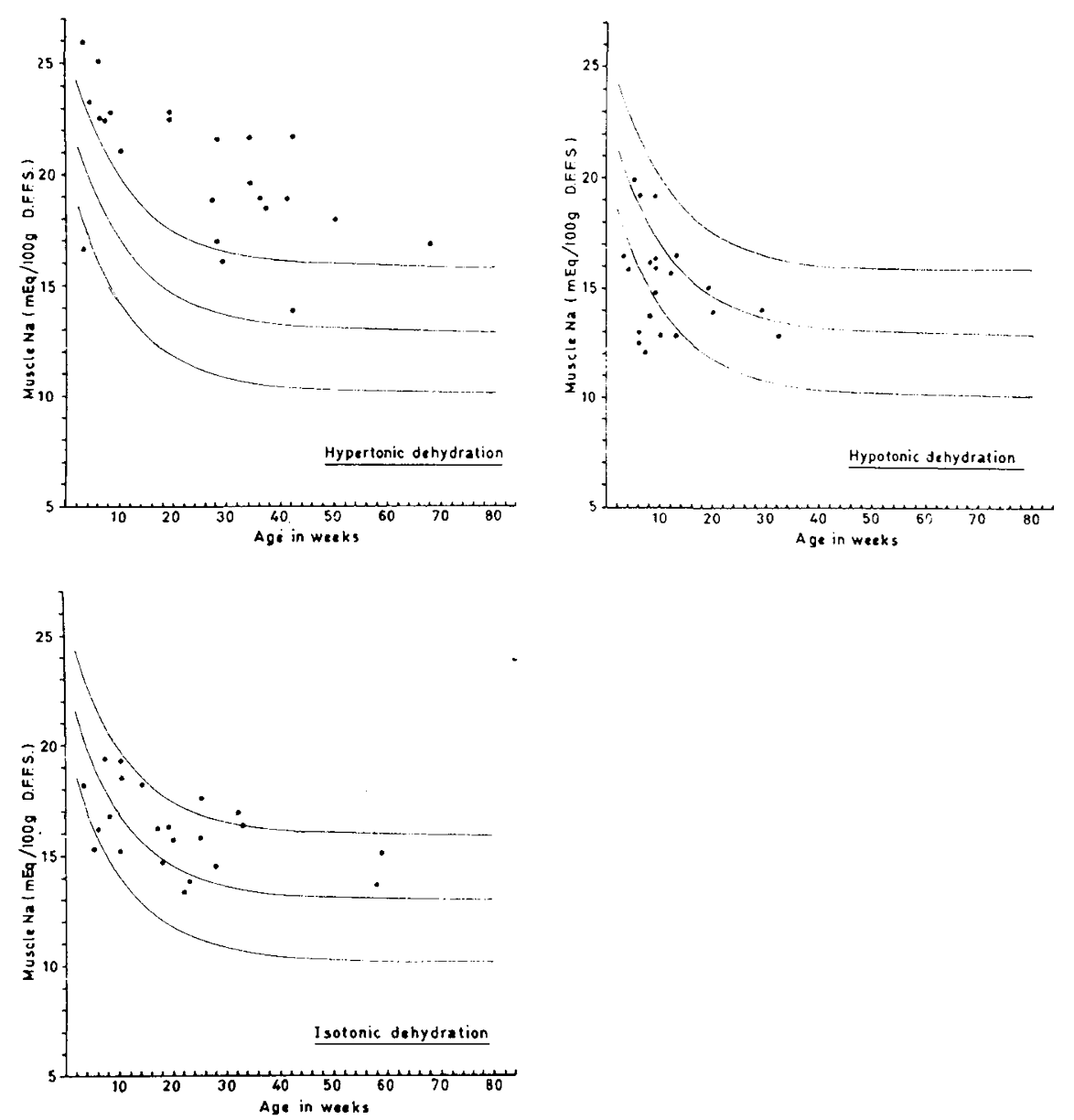

Fig. 2. Sodium content of muscle in the three groups of dehydrated children. The results are presented in comparison to the mean $\pm 2 \mathrm{sD}$ calculated in relation to age for individual values of a reference group. D.F.F.S.: dry fat-free solid.

ologic condition observed. These circumstances are favorable for the study of the consequences of acute hydroelectric disturbances consecutive to important fecal losses on the variations of tissue composition in children.

We were not able to show important variations of the intracellular elements in the majority of these dehydrated children. Indeed, all except three of the phosphorus values were within normal limits (Fig. 5), and only 14 out of 66 dehydrated children presented a significantly decreased value of muscle potassium (Fig. 4). These last data imply that, in the majority of cases, there was no important cellular depletion of potassium; this finding disagrees with the data obtained through water and ionic balances $[5,6,24]$ but can be explained by the short interval between the onset of the illness and the investigation. Thus it seems that, under conditions of acute dehydration, the most important variations of muscle composition are those of hydration and, to a smaller extent, those of sodium and chloride content.

In hypertonic dehydration, an important reduction in water (20 of 23 cases) and an increase in sodium (20 of 23 cases) and chloride content (15 of 23 cases) were observed in muscle tissue. Since potassium content remained normal in the majority of cases, there was hypertonicity of tissular water.

In hypotonic dehydration, in the great majority of cases (19 of 21), muscle tissue remained normally hydrated and there was, in one-third of all cases, a low sodium and chloride content. Hypotonicity of tissular water was observed.

In isotonic dehydration, the data were more variable. Nevertheless, as shown in Figure 1, all the data but four were below the mean value of the reference group; and in 10 of the 22 cases studied, a significant dehydration of the muscle tissue was observed.

Observations on cutaneous tissue show essential dif- 

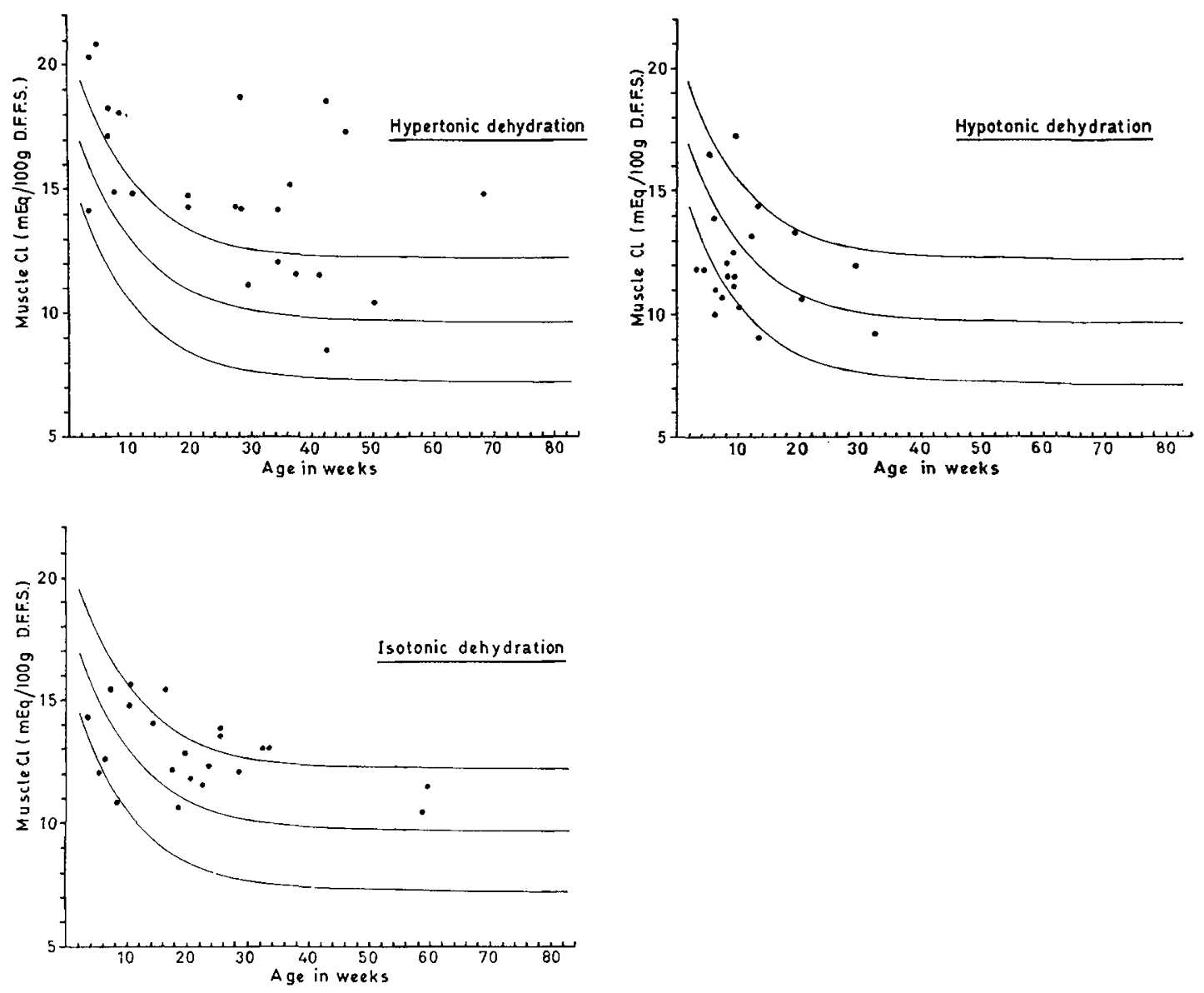

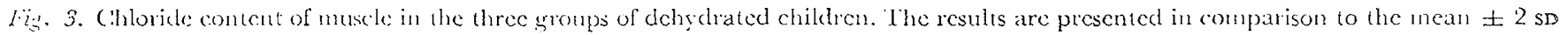
calculated in relation to age for indiv idual values of a reference group. D.F.F.S.: dry fat-frec solid.
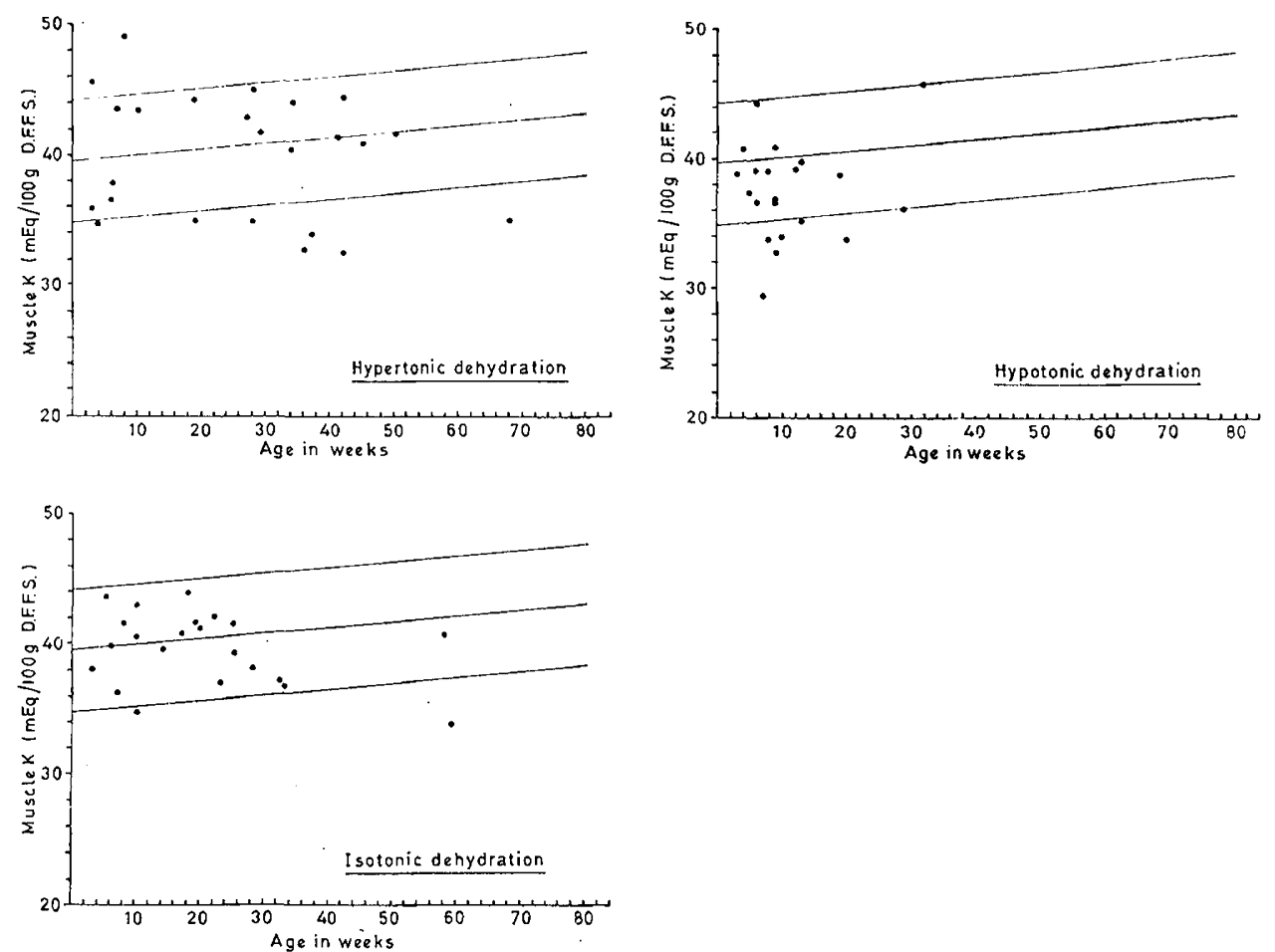

Fig. 4. Potassinn content of muscle in the three groups of dehydrated children. The results are presented in comparison to the mean \pm 2 sD cialculated in relation to age for individual values of a reference group. D.F.F.S.: dry fat-free solid. 

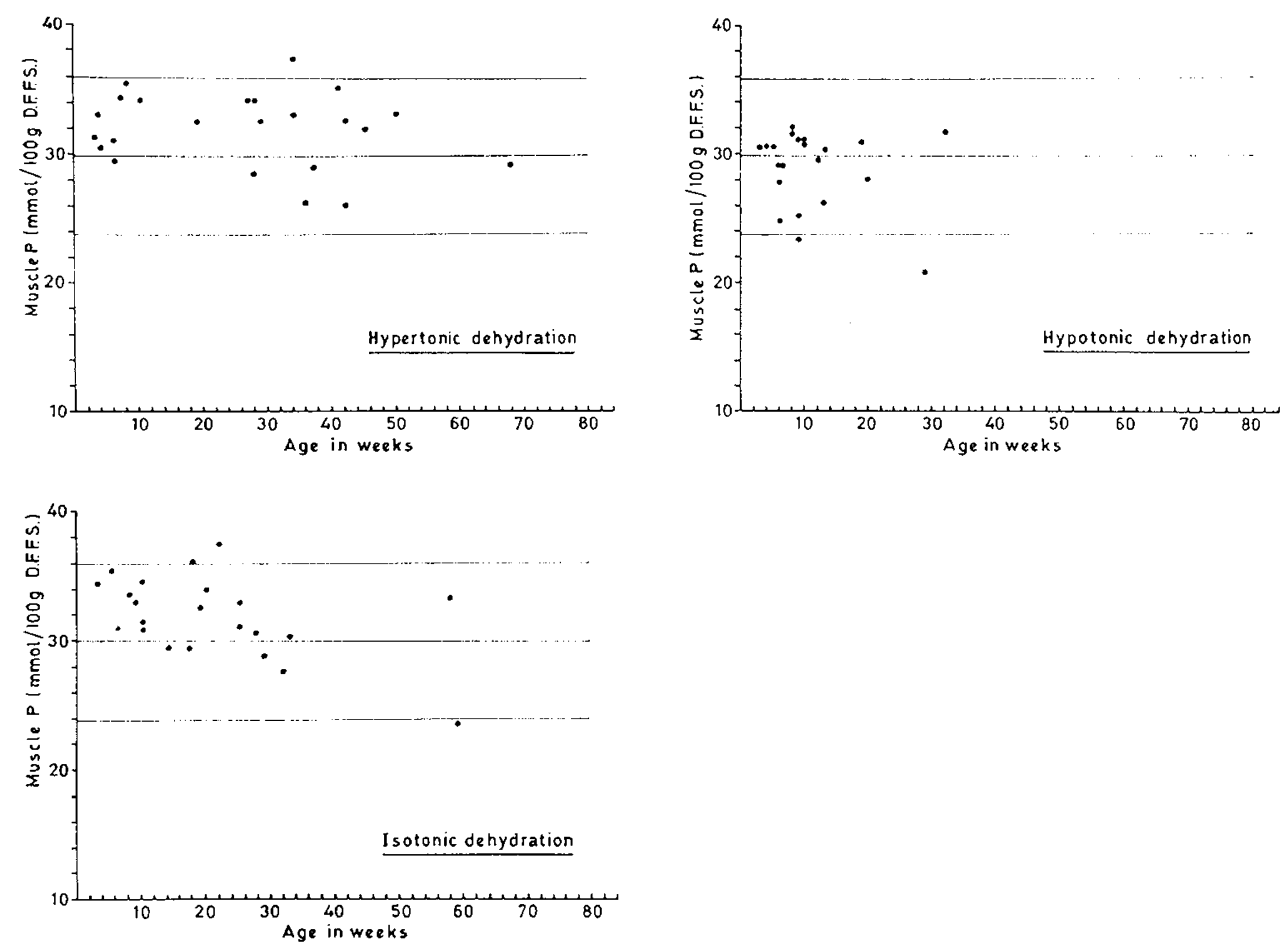

Fig. 5. Phosphorus content of muscle in the three groups of dehydrated children. The results are presented in comparison to the mean \pm 2 sD calculated in relation to age for individual values of a reference group. D.F.F.S.: dry fat-free solid.

ferences; whatever the form of dehydration, it is usual to note dryness and reduced turgor of cutaneous tissue. The results of our skin analyses showed that in the majority of the cases of dehydration, including hypotonic dehydration where the muscle tissue is, in most cases, normally hydrated, there was an important reduction of skin water content without any detectable changes in the amount of electrolytes and phosphorus (Figs. 6 and 7).

The differences in behavior of the muscle and skin tissues resulting from acute variation in body hydration were made clear in a study of two groups of children; one with hypertonic dehydration (group I) and one with hypotonic dehydration (group II). Two samples of muscle and skin tissue were taken: the first at the time of admission and the second after complete recovery. As is shown in Figure 8, the body rehydration in all the children of group $I$ was accompanied by an increase of muscle and skin hydration. However, in the case of children with hypotonic dehydration, the increase of cutaneous hydration during treatment was not accompanied by any significant variations of the amount of muscle water.

These observations confirm to a great extent the data collected by the analysis of various tissues in experimental hyponatremia or dehydration: in rats sub- mitted to acute hyponatremia without dehydration, Woodbury [34] observed that the skin reacts to the decrease of extracellular osmolarity in a way which differs from other tissues: the skin dehydrates without loss of electrolytes, whereas a cellular hydration associated with a loss of ions occurs in muscle and heart tissues. As the total body water did not vary in the course of his experiment, the author infers that in acute hyponatremia there is a transfer of cutaneous water toward other tissues which are richer in cells. $\mathrm{He}$ concludes that under these conditions skin acts as a storage source of water.

Other experiments, mainly related to the variations in the amount of water of the various tissues in experimental dehydration, confirm the particular role played by the cutaneous tissue: the skin loses more water than the other tissues. In overhydration, the cutaneous tissue accepts almost half of the added water [20]. Eichelberger et al. [15] found direct evidence that "skin is a reservoir capable of taking a very considerable part of any fluid added to the body." Additionally, it has been shown with dogs that acute dehydration produced by hemorrhage or by infusion of hypertonic sucrose is not accompanied by any change in the quantity of muscle water, whereas there is a $7 \%$ loss of skin water [8].

In the light of our observations and of the experi- 

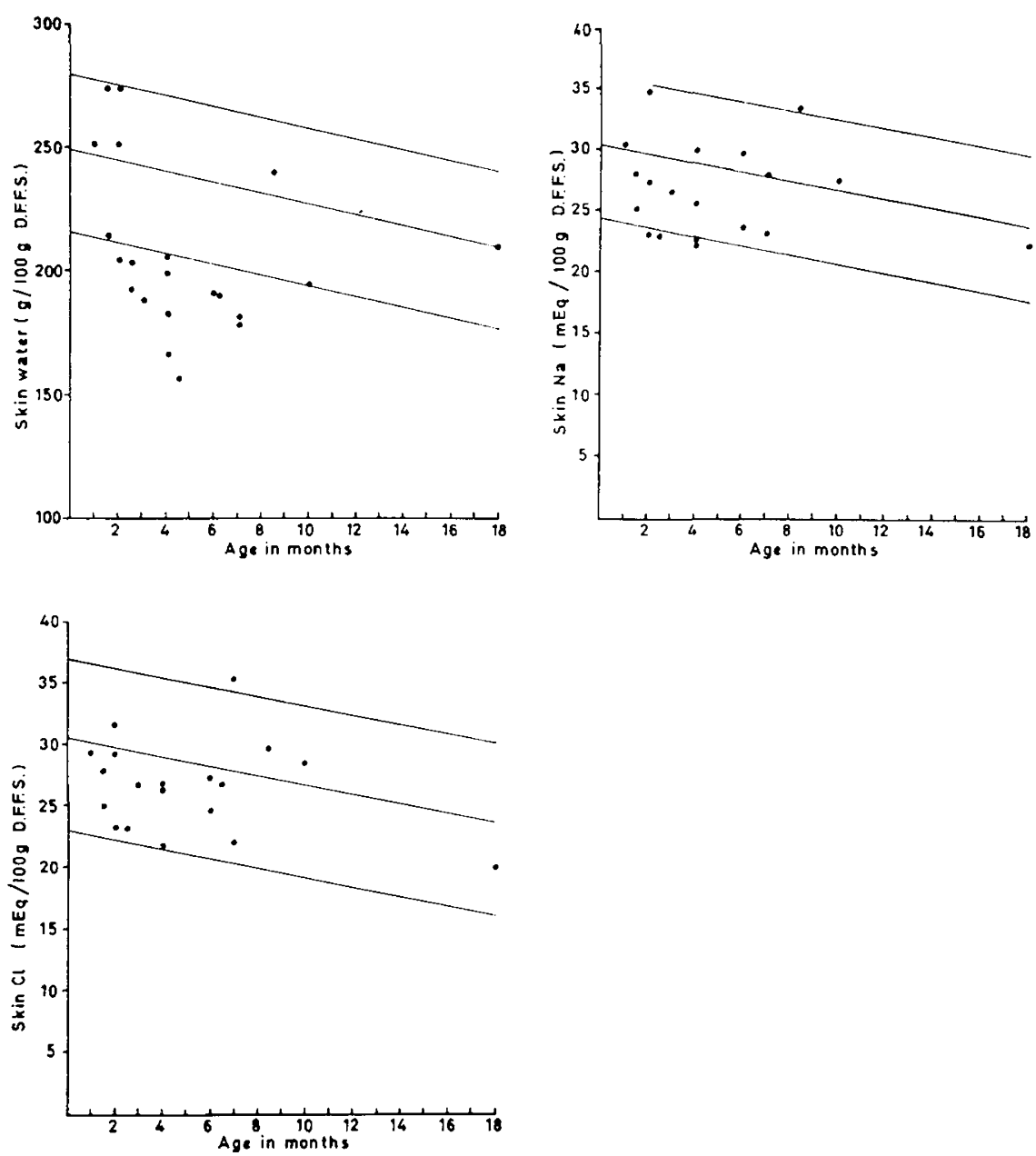

Fig. 6. Water, sodium, and chloride content of skin in acute dehydration in children. The results are presented in comparison to the mean \pm 2 sD calculated in relation to age for individual values of a reference group. D.F.F.S.: dry fat-free solid.
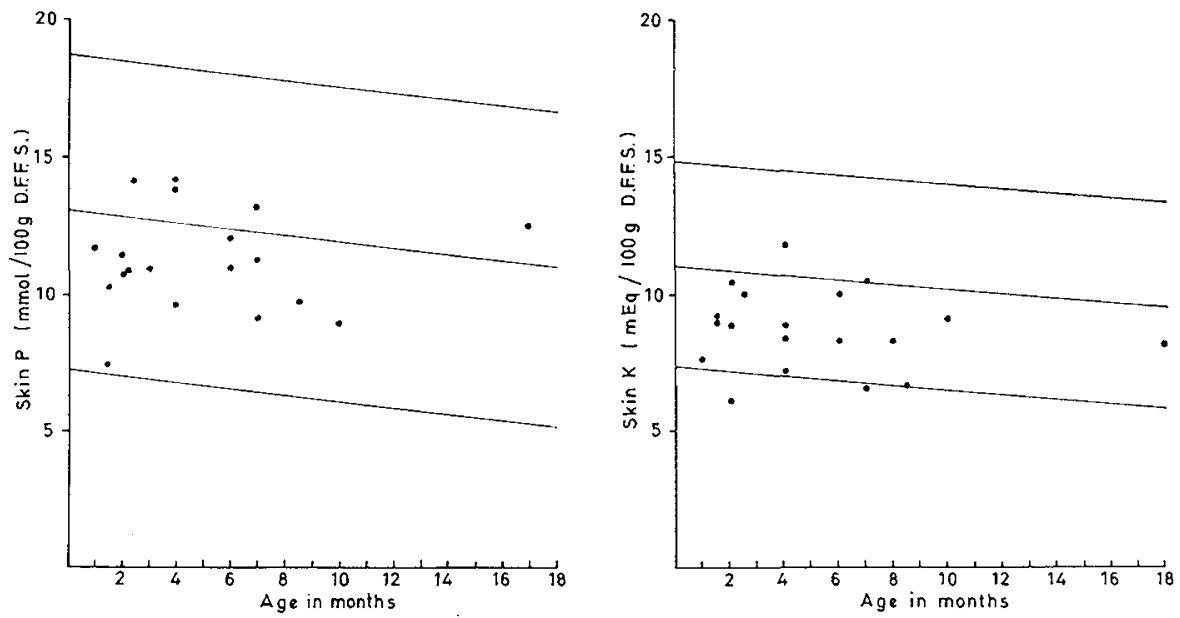

Fig. 7. Potassium and phosphorus content of skin in acute dehydration in children. The results are presented in comparison to the mean \pm 2 sD calculated in relation to age for individual values of a reference group. D.F.F.S.: dry fat-free solid. 

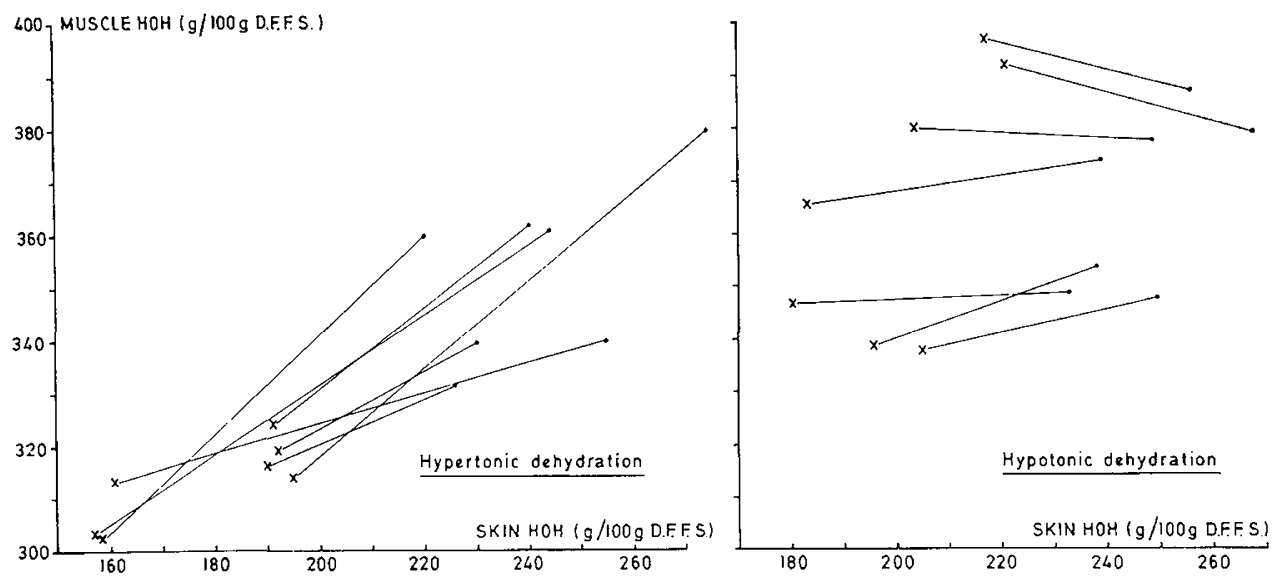

Fig. 8. Variation of muscle and skin hydration with the dry fat-free solids (D.F.F.S.) as the basis of reference during treatment of hypertonic dehydration (left $)$ and hypotonic dehydration $($ right $)$. X: First analysis, before any therapy. $\bullet$ : Second analysis, after complete recovery.

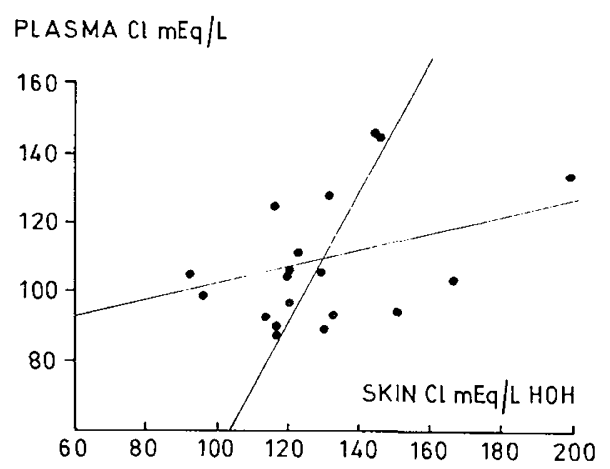

Fig. 9. Relation between plasma chloride concentration and the concentration of chloride in skin water in children with acute dehydration. $n=19, r=0.36, P>0.1$.

mental data which have been reported, it clearly appears that the cutaneous tissue, which is hardly cellularized, behaves quite differently from the muscle tissue, which is very rich in cells.

With respect to the available data, it is not possible to define the mechanisms through which skin reacts in a way different from other tissues in response to the variations of body hydroelectrolytic equilibrium. Skin is very poor in cells, and the explanation proposed by Rotman [29], based on his own experiments and on those of De Boer [8], is that skin is better adapted to this function of reservoir than other tissues because its water content and salt concentration can be changed independently.

This idea seems now to be confirmed by the study of the chemical structure of skin and collagenous tissue $[2,23,26]$, by studies of experimental dehydration and sodium depletion in rabbits $[16,33]$, and through investigations in relation to edema in rats [27].
In all of the dehydrated children, there was no strong statistical correlation between the variations of chloremia and the concentration of chloride in cutaneous water (Fig. 9). This observation confirms that the movement of water between plasma and skin are not accompanied by parallel movement of chloride ions. It is possible that the fraction of cutaneous chloride which may be linked to the connective tissue is not freely diffusible and thus cannot be quickly mobilized.

In muscle tissue, the situation is quite different; there is a significant correlation between the variations

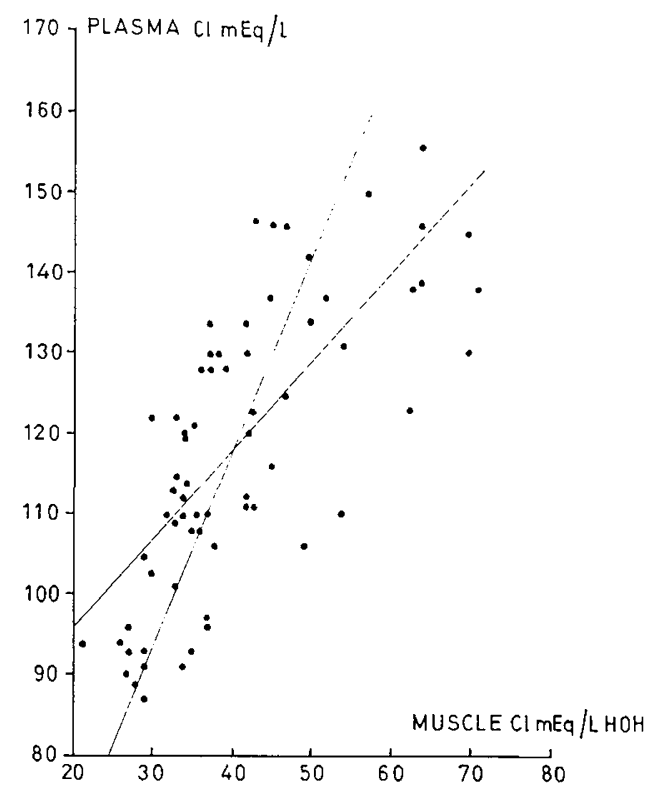

Fig. 10. Relation between plasma chloride concentration and the concentration of chloride in muscle water in children with acute dehydration. $n=66, r=0.68, P<0.001$. 
of chloremia and of the concentration of chloride in muscle water (Fig. 10). This last phenomenon has been experimentally observed in different tissues (muscle, liver, lung; and kidney) [1].

\section{Conclusion}

The variations of tissue composition in acute dehydration as observed in this study can be interpreted from a dynamic point of view. Indeed, the main factors causing the dehydration process are, in the case of the infants studied, an increase of the fecal losses and, to a lesser extent, the accentuation of the skin and pulmonary water losses secondary to fever. However, stool analyses show that if their composition is extremely variable, namely in the concentration of sodium and potassium, they are always hypotonic in relation to plasma [3, 6, 18, 23, 24, 31, 32]. As evaporative losses are also poor in electrolytes and since, in severely dehydrated children, glomerular filtration is reduced, acute diarrhea by itself must lead in most cases to a hypertonic form of dehydration and thus to a generalized hypertonia of all the tissues of the organism. This is the case for muscle and skin tissues which, as we have shown, are dehydrated and hypertonic. Certain studies allow us to think that the same process occurs in cerebral tissue, resulting in intracranial hemorrhages and convulsions $[9,17,19,22,30]$.

Hypotonic dehydration has been observed in children who received variable quantities of liquid poor in electrolytes (sugar and water, rice water, unsalted carrot soup) as soon as diarrhea appeared. These supplies are insufficient to avoid the persistence of a certain state of global dehydration. Since the balance of electrolytes continues to be negative, hypertonicity is translated into an iso- or even a hypotonicity. Nevertheless the supplies are sufficient to start a rehydration of muscle tissue which contains, in most of the cases of hypotonic dehydration that we have studied, a normal quantity of water.

Under the same conditions the cutaneous tissue remains dehydrated and its composition becomes normal only after the correction of the global dehydration.

Everything happens as though the cutaneous tissue played a protecting role to maintain homeostasis of tissues which are richer in cells, such as muscle.

Appendix 1

Individual Clinical and Biologic Data on Admission of the Children with Hypertonic Dehydration.

\begin{tabular}{|c|c|c|c|c|c|c|c|c|c|c|c|c|c|c|c|c|c|c|c|c|c|c|c|}
\hline \multirow[b]{2}{*}{$\begin{array}{c}\text { Patient } \\
\text { no. }\end{array}$} & \multicolumn{6}{|c|}{ Patient data } & \multicolumn{7}{|c|}{ Plasma values } & \multicolumn{5}{|c|}{ Muscle values/100 g DFFS 1} & \multicolumn{5}{|c|}{ Skin values $/ 100 \mathrm{~g}$ DFFS } \\
\hline & $\ddot{\dot{s}}$ & $\begin{array}{l}\ddot{2} \\
\dot{3} \\
\dot{8}\end{array}$ & 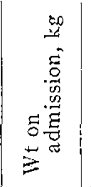 & 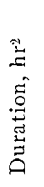 & $\begin{array}{l}20 \\
0 \\
0 \\
0 \\
0 \\
=\end{array}$ & 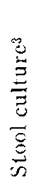 & 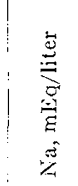 & 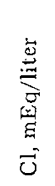 & 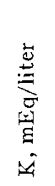 & $\begin{array}{l}\text { 垔 } \\
\text { 品 } \\
\text { 号 }\end{array}$ & 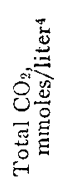 & 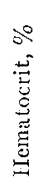 & 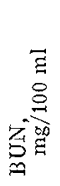 & 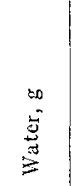 & 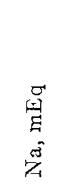 & $\begin{array}{l}\vec{f} \\
\vec{\Xi} \\
\overrightarrow{0}\end{array}$ & 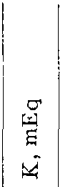 & $\begin{array}{l}\frac{\mathscr{J}}{0} \\
\stackrel{\Xi}{\Xi} \\
\text { : }\end{array}$ & 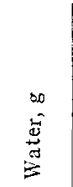 & 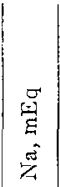 & $\begin{array}{c}\sigma \\
\text { 珀 } \\
\vec{v}\end{array}$ & 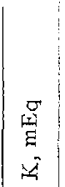 & $\begin{array}{l}\frac{\mathfrak{s}}{c} \\
\stackrel{G}{G} \\
\stackrel{\Xi}{\Xi} \\
\text { ai }\end{array}$ \\
\hline 1 & F & 3 & 3.850 & 24 & 12 & $\mathrm{~S}$ & 157 & 128 & 7.2 & 7.30 & 14.2 & 45 & 108 & 293.3 & 26.8 & 20.4 & 35.8 & 31.3 & & & & & \\
\hline 2 & $\mathrm{~F}$ & 19 & 6.250 & 36 & 10 & $\mathrm{C}$ & 153 & 116 & 5.3 & 7.24 & 9.5 & 36 & 72 & 328.5 & 22.9 & 14.7 & 34.9 & & & & & & \\
\hline 3 & $\mathrm{M}$ & 6 & 3.900 & 24 & 11 & $\mathrm{~S}$ & 153 & 138 & 5.2 & 7.16 & 10.0 & 52 & 65 & 310.5 & 22.6 & 18.3 & 37.9 & 31.1 & & & & & \\
\hline 4 & $F$ & 8 & 4.700 & 36 & 14 & $\mathrm{C}$ & 174 & 150 & 6.1 & 7.24 & 12.1 & 41 & 143 & 320.2 & 22.9 & 18.1 & 49.6 & 35.7 & & & & & \\
\hline 5 & $\mathrm{M}$ & 11 & 5.200 & 48 & 12 & & 158 & 137 & 6.8 & 7.21 & 12.8 & 39 & 148 & 351.3 & 21.1 & 14.8 & 43.5 & 34.2 & & & & & \\
\hline 6 & M & 3 & 4.200 & 48 & 10 & $\mathrm{~S}$ & 162 & 146 & 5.7 & 7.21 & 9.6 & 39 & 186 & 301.1 & 16.7 & 14.1 & 45.5 & 33.1 & & & & & \\
\hline 7 & $\mathrm{M}$ & 7 & 3.750 & 48 & 10 & & 159 & 116 & 3.9 & 7.31 & & & 93 & 349.7 & 22.5 & 14.9 & 43.9 & 34.5 & & & & & \\
\hline 8 & $\mathrm{M}$ & 4 & 4.200 & 36 & 11 & & 165 & 156 & 5.6 & 7.10 & 9.1 & 38 & 112 & 329.0 & 23.4 & 20.9 & 40.6 & 30.4 & & & & & \\
\hline 9 & $M$ & 5 & 4.150 & 24 & 13 & $\mathrm{~S}$ & 156 & 137 & 5.9 & 7.11 & 7.3 & 49 & 69 & 331.8 & 25.2 & 17.1 & 36.5 & 29.6 & 192.4 & 23.2 & 10.0 & 14.2 & \\
\hline 10 & $\mathrm{M}$ & 42 & 7.900 & 48 & 18 & $\mathrm{~S}$ & 155 & 122 & 5.9 & 7.24 & 11.6 & 59 & 108 & 285.4 & 13.9 & 8.5 & 44.5 & 32.6 & & & & & \\
\hline 11 & $\mathrm{M}$ & 50 & 8.800 & 48 & 15 & & 154 & 120 & 3.6 & 7.19 & 7.1 & & 58 & 304.8 & 18.0 & 10.5 & 41.7 & 33.2 & & & & & \\
\hline 12 & $\mathrm{M}$ & 27 & 7.100 & 24 & 10 & C & 160 & 123 & 5.5 & 7.29 & 10.0 & 40 & 73 & 328.8 & 18.8 & 14.3 & 43.0 & 34.2 & & & & & \\
\hline 13 & $\mathrm{M}$ & 35 & 7.600 & 24 & 12 & & 164 & 123 & 4.3 & 7.08 & 7.6 & 41 & 88 & 242.6 & 19.0 & 15.2 & 32.8 & 26.3 & & & & & \\
\hline 14 & $\mathrm{M}$ & 28 & 7.150 & 36 & 11 & $\mathrm{C}$ & 174 & 139 & 4.4 & 7.21 & & 50 & 94 & 292.6 & 21.7 & 18.8 & 34.9 & 28.6 & 156.9 & & & & \\
\hline 15 & $F$ & 29 & 7.000 & 48 & 10 & & 151 & 120 & 5.3 & 7.21 & 12.3 & 42 & & 313.2 & 16.1 & 11.1 & 41.8 & 32.6 & & & & & \\
\hline 16 & $M$ & 34 & 7.600 & 36 & 13 & & 159 & 134 & 4.6 & 7.19 & 10.5 & 48 & 121 & 284.8 & 19.7 & 14.3 & 40.5 & 33.1 & & & & & \\
\hline 17 & $F$ & 34 & 6.950 & 36 & 10 & C & 167 & 147 & 4.2 & 7.09 & 15.0 & & & 279.2 & 21.8 & 12.1 & 44.2 & 37.5 & & & & & \\
\hline 18 & $\mathrm{M}$ & 43 & 8.250 & 24 & 11 & & 153 & 130 & 4.0 & 7.13 & 10.1 & 38 & 68 & 315.1 & 19.0 & 11.6 & 42.1 & 36.8 & & & & & \\
\hline 19 & $F$ & 35 & 7.150 & 24 & 10 & & 158 & 124 & 3.8 & 7.27 & 12.8 & 43 & 128 & 315.2 & 18.6 & 11.6 & 34.0 & 29.0 & & & & & \\
\hline 20 & $\mathrm{M}$ & 45 & 8.150 & 24 & 11 & & 155 & 145 & 4.9 & 7.10 & 7.6 & 40 & 100 & 314.6 & 21.3 & I7. 4 & 41.0 & 31.9 & 195.2 & 27.5 & 28.5 & 9.1 & 9.0 \\
\hline 21 & $\mathrm{M}$ & 42 & 8.300 & 48 & 18 & $\mathrm{~s}$ & 165 & 130 & 5.5 & 7.28 & 13.2 & 40 & 125 & 265.0 & 21.8 & 18.6 & 32.6 & 26.0 & & & & & \\
\hline 22 & $F$ & 24 & 6.900 & 36 & 11 & $\mathrm{~S}$ & 156 & 146 & 5.4 & 7.21 & 11.5 & 45 & 93 & 316.5 & 17.0 & 14.3 & 35.1 & 29.2 & 190.0 & 29.9 & 27.4 & 10.0 & 12.1 \\
\hline 23 & $\mathrm{~F}$ & 67 & 10.100 & 48 & 10 & $\mathrm{~S}$ & 158 & 118 & 6.7 & 7.12 & 8.7 & 45 & 131 & 276.4 & 17.0 & 14.9 & 35.1 & 29.3 & 210.0 & 22.3 & 20.0 & 8.2 & 12.6 \\
\hline
\end{tabular}

2 DFFS : dry fat-free solid.

Hours of illness before admission.

${ }^{3} \mathrm{~S}$ : Salmonella. C: enteropathogenic Escherichia coli.

${ }^{4}$ Capillary blood. 
Appendix 2

Individual Clinical and Biologic Data on Admission of the Children with Isotonic Dehydration

\begin{tabular}{|c|c|c|c|c|c|c|c|c|c|c|c|c|c|c|c|c|c|c|c|c|c|c|c|}
\hline \multirow[b]{2}{*}{$\begin{array}{l}\text { Patient } \\
\text { no. }\end{array}$} & \multicolumn{6}{|c|}{ Patient data } & \multicolumn{7}{|c|}{ Plasma values } & \multicolumn{5}{|c|}{ Muscle values $/ 100 \mathrm{~g}$ DFFS 1} & \multicolumn{5}{|c|}{ Skin values $/ 100 \mathrm{~g}$ DFFS } \\
\hline & 岕 & $\begin{array}{l}\ddot{y} \\
\ddot{2} \\
\dot{x}\end{array}$ & 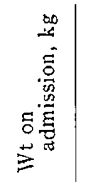 & 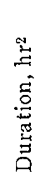 & $\begin{array}{l}50 \\
\text { के } \\
0 \\
0 \\
0 \\
\end{array}$ & 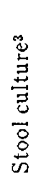 & 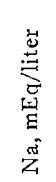 & 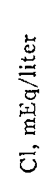 & 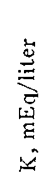 & 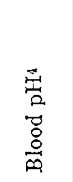 & 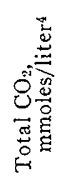 & 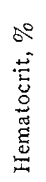 & 穹官 & 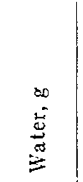 & $\begin{array}{l}\overline{\nabla j} \\
\bar{\Xi} \\
\ddot{z}\end{array}$ & 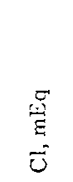 & 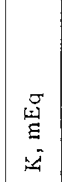 & 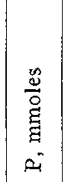 & 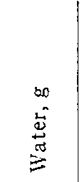 & 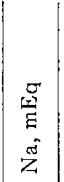 & 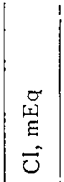 & 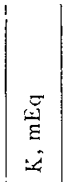 & 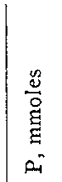 \\
\hline 24 & $\mathrm{MI}$ & 22 & 6.300 & 48 & 10 & $\mathrm{G}$ & 134 & 113 & 4.5 & 7.28 & 11.2 & 38 & 55 & 350.0 & 13.4 & 11.6 & 42.2 & 37.4 & & & & & \\
\hline 25 & $F$ & 5 & 3.950 & 48 & 11 & $\mathrm{G}$ & 140 & 121 & 6.2 & 7.24 & 8.0 & 40 & 100 & 345.7 & 15.3 & 12.1 & 43.7 & 34.5 & & & & & \\
\hline 26 & $\mathrm{M}$ & 19 & 5.650 & 36 & 11 & $\mathrm{G}$ & 136 & 128 & 5.3 & 7.22 & 12.0 & 52 & 105 & 334.8 & 16.3 & 12.9 & 40.7 & 32.4 & & & & & \\
\hline 27 & $\mathrm{~F}$ & 14 & 5.100 & 12 & 12 & $\mathrm{~S}$ & 144 & 112 & 4.2 & 7.29 & 9.5 & 34 & & 338.6 & 18.2 & 14.1 & 39.7 & 29.5 & & & & & \\
\hline 28 & $\mathrm{~F}$ & 10 & 4.400 & 24 & 10 & & 142 & 133 & 5.3 & 7.10 & 9.7 & & 87 & 300.5 & 18.5 & 15.7 & 34.9 & 31.5 & & & & & \\
\hline 29 & $\mathrm{M}$ & 3 & 3.200 & 24 & 11 & $\mathrm{C}$ & 137 & 125 & 7.0 & 7.13 & 6.1 & 57 & 75 & 322.0 & 18.2 & 14.4 & 38.0 & 34.3 & & & & & \\
\hline 30 & $\mathrm{M}$ & 10 & 4.250 & 24 & 18 & $\mathrm{C}$ & 134 & 111 & 4.8 & 7.27 & 16.4 & & 97 & 352.1 & 15.2 & 14.8 & 43.1 & 30.8 & & & & & \\
\hline 31 & $\mathrm{M}$ & 24 & 6.300 & 36 & 14 & $\mathrm{C}$ & 146 & 130 & 4.5 & 7.08 & 11.1 & 39 & & 351.5 & 17.6 & 13.9 & 39.4 & 31.1 & & & & & \\
\hline 32 & $\mathrm{MI}$ & 9 & 4.600 & 24 & 11 & & 148 & 119 & 4.4 & 7.27 & 11.9 & 32 & 38 & 333.9 & 16.9 & 10.9 & 41.7 & 33.6 & & & & & \\
\hline 33 & $F$ & 27 & 6.450 & 24 & 14 & $\mathrm{C}$ & 132 & 106 & 4.2 & 7.32 & 22.0 & 46 & 88 & 355.0 & 15.8 & 13.5 & 41.7 & 32.6 & 354.5 & 23.7 & 24.6 & 8.3 & 11.0 \\
\hline 34 & $M$ & 17 & 5.800 & 18 & 15 & & 146 & 128 & 7.1 & 7.12 & 8.2 & 36 & 116 & 340.3 & 16.2 & 12.2 & 40.8 & 29.4 & 206.0 & 30.0 & 26.8 & 8.9 & 13.5 \\
\hline 35 & $\mathrm{~F}$ & 8 & 4.250 & 48 & 17 & $\mathrm{~S}$ & 141 & 116 & 5.8 & 7.25 & 13.7 & 35 & 90 & 320.0 & 19.3 & 15.6 & 40.7 & 34.5 & & & & & \\
\hline 30 & $\mathrm{~F}$ & 18 & 5.300 & 36 & 10 & & 138 & 114 & 5.7 & 7.15 & 9.4 & 42 & 145 & 313.4 & 14.7 & 11.0 & 44.0 & 36.1 & 166.4 & 25.4 & 26.8 & $3,11.8$ & 14.1 \\
\hline 37 & F & 7 & 3.900 & 36 & 15 & $\mathrm{~S}$ & 146 & 132 & 5.3 & 7.11 & 6.8 & 37 & 93 & 311.9 & 19.4 & 15.5 & 36.3 & 32.1 & & & & & \\
\hline 38 & $\mathrm{~F}$ & 6 & 4.050 & 24 & 10 & & 132 & 115 & 4.2 & 7.28 & 10.0 & 39 & 115 & 380.5 & 16.2 & 12.7 & 39.9 & 31.0 & 274.1 & 25.2 & 25.1 & 9.2 & $\begin{array}{ll}2.3 \\
\end{array}$ \\
\hline 39 & $\mathrm{M}$ & 20 & 5.900 & 24 & 12 & & 141 & 128 & 5.8 & 7.08 & 6.4 & 46 & 123 & 321.7 & 15.7 & 11.9 & 41.2 & 33.9 & & & & & \\
\hline 40 & $\mathrm{M}$ & 29 & 7.450 & 48 & 11 & & 146 & 130 & 5.4 & 7.31 & 17.3 & & 90 & 349.8 & 13.8 & 12.4 & 37.1 & 28.6 & & & & & \\
\hline 41 & $M$ & 54 & 9.600 & 24 & 10 & & 140 & 110 & 3.5 & & 14.5 & 45 & 41 & 308.2 & 15.1 & 11.5 & 34.0 & 23.3 & & & & & \\
\hline 42 & $\mathrm{~F}$ & 58 & 9.500 & 48 & 17 & & 137 & 103 & 3.5 & 7.35 & 21.0 & 48 & 65 & 343.9 & 13.7 & 10.4 & 40.9 & 33.2 & 250.5 & 33.5 & 29.8 & 6.5 & \begin{tabular}{|l|l}
5 & 9.8
\end{tabular} \\
\hline 43 & $F$ & 28 & 7.100 & 36 & II & & 131 & 110 & 3.2 & 7.32 & 13.5 & 50 & 35 & 378.9 & 14.5 & 12.1 & 38.3 & 30.5 & & & & & \\
\hline 44 & $F$ & 31 & $7.150 !$ & 36 & 11 & $\mathrm{~S}$ & 145 & 134 & 4.2 & 7.16 & 10.1 & 37 & 57 & 311.2 & 16.3 & 13.1 & 39.6 & 30.2 & 178.9 & 27.9 & 35.5 & 510.5 & 13.2 \\
\hline 45 & $\mathrm{M}$ & 32 & 7.250 & 24 & 10 & $\mathrm{C}$ & 130 & 120 & 7.0 & 7.24 & 10.6 & & 37 & 332.3 & 17.0 & 13.8 & 37.3 & 327.5 & & & & & \\
\hline
\end{tabular}

DFFS: dry fat-free solici.

Hours of illness before admission.

S : Salmonella. G: enteropathogenic Escherichia coli.

4 Capillary blood.

Appendix 3

Individual Clinical and Biologic Data on Admission of the Children with Hypotonic Dehydration

\begin{tabular}{|c|c|c|c|c|c|c|c|c|c|c|c|c|c|c|c|c|c|c|c|c|c|c|c|}
\hline \multirow[b]{2}{*}{$\begin{array}{c}\text { Patient } \\
\text { no. }\end{array}$} & \multicolumn{6}{|c|}{ Patient data } & \multicolumn{7}{|c|}{ Plasma values } & \multicolumn{5}{|c|}{ Muscle values/100 g DFFS 1} & \multicolumn{5}{|c|}{ Skin values/100 g DFFS } \\
\hline & 峁 & $\begin{array}{l}\frac{1}{3} \\
0 \\
0 \\
0 \\
0\end{array}$ & 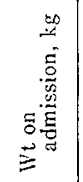 & 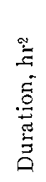 & $\begin{array}{l}5 \\
0 \\
0 \\
0 \\
0 \\
0\end{array}$ & 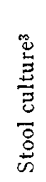 & 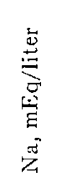 & $\begin{array}{l}\stackrel{ \pm}{ \pm} \\
\vec{E} \\
\vec{\Xi} \\
\vec{E}\end{array}$ & 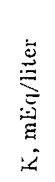 & 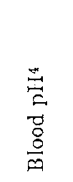 & 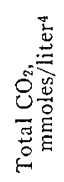 & 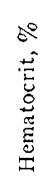 & 空官 & 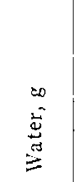 & $\begin{array}{l}\overline{\bar{z}} \\
\bar{z} \\
\bar{z}\end{array}$ & $\begin{array}{l}\stackrel{\check{E}}{\Xi} \\
\vec{j}\end{array}$ & 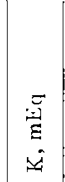 & 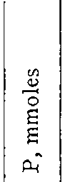 & 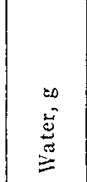 & 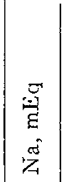 & $\begin{array}{l}\overrightarrow{\text { Ify }} \\
\overrightarrow{0}\end{array}$ & 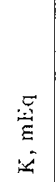 & 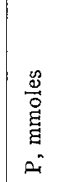 \\
\hline 46 & $M$ & 6 & 3.550 & 48 & 10 & & 122 & 108 & 6.0 & 7.21 & 10.8 & 44 & 80 & 394.0 & 19.3 & 13.9 & 44.3 & 34.7 & & & & & \\
\hline 47 & $\mathrm{~F}$ & 3 & 3.200 & 48 & 11 & & 124 & 101 & 5.5 & & 17.0 & 45 & 36 & 356.8 & 16.5 & 11.9 & 38.7 & 30.7 & & & & & \\
\hline 48 & $F$ & 14 & 5.200 & 24 & 13 & & 115 & 91 & 4.1 & 7.35 & 20.0 & & & 398.0 & 16.5 & 14.5 & 35.1 & 30.4 & & & & & \\
\hline 49 & $M$ & 4 & 4.000 & 48 & 10 & $\mathrm{C}$ & 121 & 110 & 5.5 & 7.30 & 14.9 & 44 & 56 & 350.4 & 15.9 & 11.9 & 40.8 & 30.4 & & & & & \\
\hline 50 & $\mathrm{~F}$ & 11 & 5.100 & 48 & 20 & $\mathrm{C}$ & 125 & 108 & 4.3 & 7.25 & 10.0 & 37 & 51 & 360.5 & 15.9 & 12.6 & 36.7 & 31.1 & & & & & \\
\hline 51 & $\mathrm{~F}$ & 11 & 5.000 & 48 & 18 & C & 126 & 109 & 4.6 & 7.19 & 15.0 & 47 & 68 & 347.0 & 14.9 & 11.7 & 36.8 & 23.4 & & & & & \\
\hline 52 & $\mathrm{~F}$ & 12 & 5.250 & 36 & 12 & & 125 & 110 & 5.6 & 7.16 & 9.0 & 46 & 30 & 370.9 & 15.7 & 13.3 & 39.1 & 29.9 & & & & & \\
\hline 53 & $M$ & 9 & 4.850 & 12 & 17 & $S$ & 126 & 115 & 3.4 & 7.18 & 12.1 & 38 & 112 & 380.5 & 16.4 & 11.2 & 40.8 & 31.2 & & & & & \\
\hline 54 & $\mathrm{~F}$ & 8 & 4.700 & 48 & 13 & & 126 & 112 & 5.0 & 7.17 & 11.7 & & 97 & 347.0 & 16.2 & 12.1 & 39.6 & 32.7 & & & & & \\
\hline 55 & $\mathrm{M}$ & 4 & 4.300 & 36 & 10 & & 125 & 87 & 4.1 & 7.42 & 27.0 & 33 & 56 & 392.1 & 20.0 & 16.6 & 37.3 & 30.6 & 251.6 & 30.4 & 29.5 & 7.6 & 11.7 \\
\hline 56 & $\mathrm{~F}$ & 8 & 4.400 & 12 & 11 & & 124 & 91 & 3.0 & 7.38 & 21.3 & 36 & 31 & 396.0 & 13.7 & 11.6 & 33.7 & 33.1 & 274.2 & 34.9 & 31.6 & 6.1 & 11.5 \\
\hline 57 & $\mathrm{~F}$ & 19 & 5.400 & 12 & 11 & & 121 & 97 & 4.4 & 7.31 & 16.1 & 41 & 52 & 366.9 & 15.1 & 13.4 & 38.7 & 31.0 & 183.2 & 22.7 & 21.8 & 8.4 & 9.7 \\
\hline 58 & $\mathrm{~F}$ & 19 & 5.800 & 24 & 12 & & 113 & 93 & 4.6 & 7.24 & 10.1 & 38 & 42 & 374.6 & 13.9 & 10.7 & 33.7 & 28.2 & 199.6 & 22.2 & 26,4 & 7.2 & 9.3 \\
\hline 59 & $\mathrm{M}$ & 6 & 4.050 & 48 & 11 & & 117 & 94 & 3.0 & 7.32 & 17.1 & 39 & 29 & 322.0 & 14.1 & 11.3 & 36.1 & 30.9 & & & & & \\
\hline 60 & $M$ & 6 & 3.850 & 48 & 10 & C & 111 & 85 & 4.0 & 7.39 & 19.1 & 37 & 21 & 397.5 & 13.0 & 11.1 & 36.6 & 29.1 & 217.01 & 28.1 & 27.9 & 9.0 & 10.9 \\
\hline 61 & $\mathrm{M}$ & 10 & 5.200 & 24 & 10 & C & 119 & 93 & 5.0 & 7.31 & 17.1 & 32 & 31 & 380.8 & 12.9 & 10.4 & 38.0 & 30.7 & 203.7 & & & & \\
\hline 62 & $M$ & 13 & 5.700 & 48 & 11 & & 120 & 94 & 5.5 & 7.17 & 13.1 & 30 & 46 & 401.9 & 12.9 & 9.2 & 39.7 & 26.3 & 178.8 & 26.6 & 26.8 & 8.3 & 11.0 \\
\hline 63 & $\mathrm{M}$ & 9 & 5.750 & 48 & 11 & & 127 & 93 & 6.6 & 7.44 & 24.0 & & & 368.4 & 19.2 & 17.3 & 31.7 & 24.6 & 205.4 & 23.2 & 23.2 & 8.9 & 11.9 \\
\hline 64 & $F$ & 32 & 7.150 & 24 & 10 & $\mathrm{C}$ & 121 & 111 & 5.2 & 7.27 & 16.2 & & 32 & 347.2 & 12.9 & 9.3 & 45.7 & 31.8 & 180.7 & 23.2 & 22.0 & 6.6 & 11.4 \\
\hline 65 & $F$ & 29 & 6.300 & 48 & 10 & & 122 & 96 & 3.1 & 7.41 & 26.0 & 42 & 54 & 322.0 & 14.1 & 11.3 & 36.1 & 20.9 & & & & & \\
\hline 66 & $\mathrm{M}$ & 7 & 4.250 & 48 & 11 & $\mathrm{C}$ & 112 & 90 & 5.4 & 7.40 & 22.5 & 39 & 72 & 373.5 & 12.1 & 10.8 & 36.4 & 27.3 & 252.0 & 27.4 & +29.3 & 10.5 & 10.8 \\
\hline
\end{tabular}

DFFS: dry fat-free solid.

2 Hours of illness beforc admission.

3 S: Salmonclla. C: enteropathogenic Escherichia coli.

4 Capillary blood. 
Appendix 4

Individual Clinical and Biologic Data before and after Treatment in Seven Children with Hypertonic Dehydration and in Seven Children with Hypotonic Dehydration

\begin{tabular}{|c|c|c|c|c|c|c|c|c|c|c|c|c|c|c|c|c|}
\hline $\begin{array}{l}\text { Patient! } \\
\text { no. }\end{array}$ & Sex & $\begin{array}{l}\text { Age, } \\
\text { wk }\end{array}$ & $\begin{array}{c}\text { Wt at } \\
\text { biopsy, } \\
\text { kg }\end{array}$ & $\begin{array}{c}\text { Dura- } \\
\text { tion, } \\
\mathrm{hr}^{\mathrm{l}}\end{array}$ & $\begin{array}{c}\text { Wt } \\
\text { loss, } \\
\%\end{array}$ & $\begin{array}{c}\text { Interval } \\
\text { between } \\
\text { biopsies, } \\
\text { days }\end{array}$ & $\begin{array}{c}\text { Stool } \\
\text { culture } 2\end{array}$ & $\underset{\text { liter }}{\mathrm{Na}}$ & $\underset{\text { liter }}{\mathrm{Cl} \text {, }}$ & $\underset{\text { liter }}{\mathrm{K} \text {, }}$ & $\underset{\mathrm{pH}^{3}}{\text { Blood }}$ & $\begin{array}{c}\text { Total } \\
\mathrm{CO}_{2}, \\
\text { mmoles/ } \\
\text { liter }\end{array}$ & $\begin{array}{c}\text { Hema- } \\
\text { tocrit, } \\
\%\end{array}$ & $\begin{array}{c}\mathrm{BUN} \\
\mathrm{mg} / 100 \\
\mathrm{ml}\end{array}$ & $\begin{array}{l}\text { Muscle } \\
\text { water, } \\
\quad \mathrm{g}\end{array}$ & $\begin{array}{l}\text { Skin } \\
\text { water, } \\
\mathrm{g}\end{array}$ \\
\hline \multicolumn{17}{|c|}{ Hypertonic dehydration } \\
\hline \multirow[t]{2}{*}{14} & $M$ & 28 & 7.150 & 36 & 11 & & $\mathrm{C}$ & 174 & 139 & 4.4 & 7.21 & & 50 & 94 & 293 & 157 \\
\hline & & & 7.900 & & & 10 & & 138 & 101 & 4.2 & 7.35 & 26.0 & 41 & 27 & 360 & 220 \\
\hline \multirow[t]{2}{*}{20} & $M$ & 45 & 8.150 & 24 & 11 & & & 155 & 145 & 4.5 & 7.10 & 7.6 & 40 & 100 & 314 & 195 \\
\hline & & & 9.100 & & & 9 & & 139 & 99 & 3.5 & 7.34 & 23.2 & 36 & 31 & 380 & 274 \\
\hline \multirow[t]{2}{*}{22} & $\mathrm{~F}$ & 24 & 6.900 & 36 & 11 & & S & 156 & 146 & 5.4 & 7.21 & 11.5 & 45 & 93 & 317 & 190 \\
\hline & & & 7.650 & & & 10 & & 138 & 99 & 3.6 & 7.37 & 23.4 & 38 & 31 & 332 & 226 \\
\hline \multirow[t]{2}{*}{67} & $\mathrm{~F}$ & 4 & 3.900 & 24 & 15 & & $\mathrm{~S}$ & 161 & 122 & 4.6 & 7.26 & 11.0 & 49 & 87 & 324 & 191 \\
\hline & & & 4.480 & & & 10 & & 134 & 102 & 3.9 & 7.36 & 27.0 & 39 & 28 & 362 & 240 \\
\hline \multirow[t]{2}{*}{68} & F & 46 & 7.800 & 48 & 12 & & & 159 & 130 & 4.1 & 7.19 & 9.8 & 39 & 76 & 303 & 157 \\
\hline & & & 8.730 & & & 10 & & 141 & 102 & 3.8 & 7.37 & 22.4 & 34 & 30 & 365 & 244 \\
\hline \multirow[t]{2}{*}{69} & $\mathrm{~F}$ & 30 & 7.000 & 48 & 13 & & $\mathrm{C}$ & 162 & 129 & 4.7 & 7.27 & 11.2 & 41 & 89 & 319 & 192 \\
\hline & & & 7.900 & & & 9 & & 137 & 102 & 4.1 & 7.37 & 24.1 & 36 & 27 & 340 & 230 \\
\hline \multirow[t]{2}{*}{70} & $M$ & 38 & 7.400 & 48 & 12 & & C & 164 & 134 & 4.9 & 7.19 & 10.1 & 43 & 69 & 313 & 161 \\
\hline & & & 8.300 & & & 12 & & 138 & 103 & 4.0 & 7.39 & 24.1 & 36 & 29 & 340 & 255 \\
\hline \multicolumn{17}{|c|}{ Hypotonic dehydration } \\
\hline \multirow[t]{2}{*}{55} & M & 4 & 4.300 & 36 & 10 & & & 125 & 87 & 4.1 & 7.42 & 27.0 & 33 & 56 & 392 & 252 \\
\hline & & & 4.750 & & & 9 & & 137 & 101 & 4.2 & 7.41 & 27.1 & 34 & 29 & 379 & 273 \\
\hline \multirow[t]{2}{*}{57} & $\mathrm{~F}$ & 19 & 5.400 & 12 & 11 & & & 121 & 97 & 4.4 & 7.31 & 16.1 & 41 & 52 & 367 & 183 \\
\hline & & & 6.000 & & & 10 & & 137 & 102 & 4.1 & 7.37 & 23.4 & 37 & & 374 & 239 \\
\hline \multirow[t]{2}{*}{60} & $M$ & 6 & 3.850 & 48 & 10 & & G & 111 & 85 & 4.6 & 7.39 & 19.1 & 37 & 21 & 397 & 217 \\
\hline & & & 4.250 & & & 9 & & 135 & 99 & 4.3 & 7.39 & 22.4 & 31 & 22 & 387 & 256 \\
\hline \multirow[t]{2}{*}{61} & $M$ & 10 & 5.200 & 24 & 10 & & $\mathrm{C}$ & 119 & 93 & 5.0 & 7.31 & 17.1 & 32 & 31 & 380 & 204 \\
\hline & & & 5.700 & & & 11 & & 137 & 103 & 4.1 & 7.42 & 27.6 & 32 & & 378 & 249 \\
\hline \multirow[t]{2}{*}{64} & $\mathrm{~F}$ & 32 & 7.150 & 24 & 10 & & $\mathrm{C}$ & 121 & 111 & 5.2 & 7.27 & 16.2 & & 32 & 347 & 181 \\
\hline & & & 7.860 & & & 10 & & 139 & 101 & 4.7 & 7.39 & 26.4 & 34 & 27 & 349 & 233 \\
\hline \multirow[t]{2}{*}{71} & $\mathrm{~F}$ & 9 & 4.100 & 48 & 10 & & & 116 & 89 & 6.6 & 7.40 & 24.1 & & & 338 & 205 \\
\hline & & & 4.500 & & & 11 & & 136 & 102 & 4.1 & 7.41 & 26.0 & & 21 & 348 & 250 \\
\hline \multirow{2}{*}{72} & $\mathrm{~F}$ & 26 & 6.100 & 48 & 12 & & S & 119 & 92 & 4.0 & 7.29 & 11.0 & 4.3 & 49 & 339 & 196 \\
\hline & & & 6.830 & & & 12 & & 141 & 102 & 3.7 & 7.41 & 26.2 & & 32 & 354 & 236 \\
\hline
\end{tabular}

${ }^{1}$ Hours of illness before admission.

2 S : Salmonella. C: enteropathogenic Escherichia coli.

${ }^{3}$ Capillary blood.

\section{References and Notes}

1. Amberson, W. R., Nash, T. P., Mulder, A. J., and Binns, D.: The relationship between tissue chloride and plasma chloride. Amer. J. Physiol., 122: 224 (1938).

2. BEAR, R. S.: The structure of collagen fibrils. Advan. Protein Chem., 7: 69 (1952).

3. Bruck, E., Abal, G., And Aceto, T., JR.: Pathogenesis and pathophysiology of hypertonic dehydration in infants with diarrhea: A clinical study of 59 infants with observations of respiratory and renal water metabolism. Amer. J. Dis. Child., 115: 122 (1968).

4. Danowski, T. S., Austin, A. C., Gow, R. C., Mateer, F. M., Weigand, F. A., Peters, T. H., and Greenman, L.: Electrolytes and nitrogen balance studies in infants following cessation of vomiting. Pediatrics, 5: 57 (1950).

5. Darrow, D. C., Harrisson, H. E., and Taffele, M.: Tissue electrolytes in adrenal insufficiency. J. Biol. Chem., 130: 487 (1939).

6. DARRow, D. C.: Retention of electrolyte during recovery from severe dehydration due to diarrhea. J. Pediat., 28: 515 (1946).

7. Darrow, D. C., Pratr, E. L., Flett, J., Gamble, A. L., and Wiese, H. F.: Disturbances of water and electrolytes in infantile diarrhea. Pediatrics, 3: 129 (1949).

8. DE BOER, B.: Alteration in the blood and in the water, fat and chloride content of tissues during dehydration in the dog. Ph.D. thesis, University of Missouri (1942).

9. Deleon, A. S., And Bergstrom, W. H.: Hypertonic dehydration. N. Y. State J. Med., 64: 2157 (1964).

10. Dubors, J.: Etude de l'Équilibre Hydro-électrolytique du Tissu Musculaire Strié chez l'Enfant. (Arscia, Brussels and Maloine, Paris, 1970). 
11. Dubors, $\mathrm{J}$.: Water and electrolyte content of human skeletal muscle. Variations with age (In preparation).

12. Dubois, J., Colard, J., and VIs, H. L.: Muscle electrolyte composition determined by neutron activation. A preliminary study of dehydration in infants. J. Nucl. Med., 7: 827 (1966)

13. Dubors, J., Colard, J., and Vis, H. L.: The study of hydroelectrolytic metabolism in man by muscular biopsies analysis (with special reference to neutron activation). J. Nucl Biol. Med., 39: 10 (1966).

14. Dubors, J., Colard, J., and VIs, H. L.: Application de I'activation neutronique à l'étude des troubles hydroelectrolytiques en pathologie infantile. In: Nuclear Activation Techniques in the Life Sciences, p. 545. (I. A. E. A., Vienna, 1967).

15. Eichelberger, L., Eisele, C. W., AND Wertzler, D.: The distribution of water, nitrogen, and clectrolytes in skin. J. Biol. Chem., 131: 177 (1943).

16. Farber, S. J.: Mucopolysaccharides and sodium metabolism. Circulation (Suppl.), 21: 94 (1960).

17. Finberg, L.: Pathogenesis of lesions in the nervous system in hypernatremic states. Pediatrics, 23: 40 (1959).

18. Finberg, L., Cheung, C. S., and Fleishman, E.: The significance of the concentration of electrolytes in stool water during infantile diarrhea. Amer. J. Dis. Child., 100: 809 (1960).

19. Finberg, L., Lutrrell, C., and Redd, H.: Pathogenesis of lesions in the nervous system in hypernatremic states. Pediatrics, 23: 46 (1959)

20. Flemister, L. J.: Distribution of available water in the animal body. Amer. J. Physiol., 135: 430 (1941-1942).

21. Hamilton, B., and Schwartz, R.: The composition of tissue in dehydration. J. Biol. Chem., 109: 745 (1935).

22. Harrisson, H. E., AND Finberg, L.: Hypernatremic dehydration. Pediat. Clin. N. Amer., 11: 455 (1964).

23. Holt, L. E., Courtney, A. M., and Fales, H. L.: The chemical composition of diarrheal as compared with normal stools in infants. Amer. J. Dis. Child., 9: 213 (1915).

24. Kooh, J. W., ANd Metcoff, J.: Physiologic considerations in fluid and electrolyte therapy with particular reference to diarrheal dehydration in children. J. Pediat., 62: 107 (1963).

25. MCCANCE, R. A., AND Robinson, J. R.: The effect of dehydration by hypertonic saline on the water content of a number of organs in the rat. Biochem. J., 47: 25 (1950).

26. Metcoff, J.: Regulation of the body fluids. In: R. E. Cook: The Biologic Basis of Pediatric Practice, Chapt. 7, p. 105. (McGraw-Hill, New York, 1968).
27. Metcoff, J., and Janeway, C. A.: Studies on the pathogenesis of nephrotic edema. J. Pediat., 58: 640 (1961).

28. Robinson, J. R., And McCANCE, R. A.: Water metabolism. Annu. Rev, Physiol., 14: 115 (1952).

29. Rotman, S.: Physiology and Biochemistry of the Skin. (University of Chicago Press, Chicago, 1954).

30. Sotos, J. F., Dodge, P. R., Meara, P., and Talbot, N. B.: Studies in experimental hypertonicity. I. Pathogenesis of the clinical syndrome, biochemical abnormalities and cause of death. Pediatrics, 26: 925 (1960).

31. Teree, T. E., Mirabal-Font, E., Ortiz, A., and Wallace, W. M.: Stool losses and acidosis in diarrheal disease of infancy. Pediatrics, 36: 704 (1965).

32. Weil, W. B., and Wallace, W. M.: Hypertonic dehydration in infancy. Pediatrics, $17: 171$ (1956).

33. Weil, W. B., AND Wallace, W. M.: The effect of alterations in extracellular fluid on the composition of connective tissue. Pediatrics, 26: 915 (1960).

34. Woonbury, D. M.: Effect of acute hyponatremia on distribution of water and electrolytes in various tissues of the rat. Amer. J. Physiol., 281: 185 (1956).

35. YANNET, H.: Changes in the brain resulting from depletion of extracellular electrolytes. Amer. J. Physiol., 128: 683 (1940).

36. Yanner, H., and Darrow, D. C.: The effect of depletion of extracellular electrolytes on the chemical composition of skeletal muscle, liver, and cardiac muscle. J. Biol. Chem., 134: 721 (1940).

37. All procedures have been performed in accordance with the provisions set forth in the Declaration of Helsinki.

38. I wish to express my gratitude to Professor H. L. Vis, Department of Pediatrics, Université Libre de Bruxelles, with whose help this study was initiated and who provided invaluable advice and encouragement. I am also grateful to M. J. Colard, (Centre de l'Energie Nucléaire, Mol, Belgium) for his very helpful assistance in neutron activation analysis.

39. This work was supported by a grant of the Fonds de la Recherche Scientifique Médicale Belge and was partially realized under Contract of the Ministère de la Politique Scientifique as part of the Association Contract Euratom, University of Brussels and University of Pisa.

40. Requests for reprints should be addressed to: JACQues Dubors, M.D., Hôpital Universitaire St. Pierre, rue Haute 320, 1000 Brussels, Belgium.

41. Accepted for publication September 7, 1971. 